\title{
STATE AND LOCAL INCENTIVES AND TECHNIQUES FOR URBAN RENEWAL
}

\author{
Whutas L. SLAYron*
}

State and local incentives and techniques for urban renewal fall under three basic categories. The first is state enabling legislation granting municipalities the authority to utilize the property tax in some special way to assist urban renewal activities. The second general category covers state financial and technical assistance to municipalities. A few states have adopted such measures, but they are not widespread. The third general category relates to municipalities only. It covers the activities undertaken by a municipality under its own authority to assist urban renewal. This is the area where the greatest assistance to the program can take place; and it is also the area where urban renewal has met its greatest impediment.

\section{1}

\section{Use of Property TAX}

\section{A. Tax Abatement}

In the 1930's and 1940's, many states adopted laws generally entitled "Limited Dividend Housing Corporation Law." The purpose of these laws was to encourage private developers to undertake slum clearance activities and produce housing for low- or moderate-income families. Incentives offered were two: tax abatement and the power of eminent domain. In these early days, the only effective program for slum clearance was public housing, and these laws were passed to add an additional tool to the slum clearance program. At this time there was no federal aid program assisting cities financially so that the cost of the land could be written down to its new, reuse value. Tax abatement, therefore, provided the same financial incentive as does the "write down" under the present federal program.

With these incentives, of course, went limitations and controls. Dividends were limited (usually to six per cent of the value of the stock), rents were frequently controlled, and the project had to be reviewed and approved by a local and/or state board.

- When these laws were passed, it was hoped that insurance companies would make considerable use of them, and additional legislation was passed permitting insurance

- A.B. 1940, M.A. 1943, University of Chicago. Urban Renewal Consultant. Partner, 1. M. Pei and Associates. Recipient of Ford Foundation Grant for the study of Urban Renewal. Former Vice President, Webb \& Knapp, Ine; former Associate Director, Urban Redevelopment Study; former Assistant Director, National Association of Housing and Redevelopment Officials. Author, THE Furure of Citjes asd Urban Redevelopsext (1951), Urban Redevelopsient Problens and Practices (igisi). Contributor to periodicals of articles on urban renewal.

${ }^{2}$ For a tabulation of the twenty-two states with such legislation, see Gazzolo, The States in Housing and Urban Renewal, Boor of the States 421 (1959). 
companies to invest in direct ownership and management of rental housing projects. These laws seemed particularly appropriate, for insurance companies, as investors, do not demand a high rate of return on their capital; and with the incentive of tax abatement, it was felt they would be able to achieve the return allowed by the law.

The tax abatement features in these laws vary among the states, but the most general provision is a freezing of the taxes or the assessment at the amount prior to the undertaking of the project. This freeze continues for a specified number of years. In orher instances, the taxes are based on a percentage of the normal assessment, and this lower assessment continues for a specified number of years. For example, the Missouri law ${ }^{2}$ taxes only the land for tire first ten years and only at its assessed value prior to development. For the next fifteen years, the land and improvements are taxed at "fifty percent of the true value of such real property." In New York" the property is assessed at fifty per cent of what would-be its normal valuation, and the lower assessment may continue for a maximum of thirty years.

Although tax abatement came into the picture via the limited dividend housing laws, it gradually crept into redevelopment as well. State redevelopment laws provide for limited dividend redevelopment corporations and establish limitations on earnings in addition to granting tax abatement and the power of eminent domain.

In nearly all instances, these limited dividend corporation laws provide for the power of eminent domain to permit the assembly of sites. Usually it is granted directly to the limited dividend corporation, but in some instances the city exercises the authority and turns the property over to the corporation after being reimbursed in full for its costs.

The early laws did not produce the activity hopefully anticipated by their sponsors. The incentives were not generally sufficient to induce many insurance companies or private developers to undertake such projects. There have been a few notable projects, of which Stuyvesant Town, built by Metropolitan Life Insurance Company, is perhaps the best known. Another successful early project erected under such a law is Quality Hill in Kansas City, Missouri, built by Lewis Kitchen.

The Missouri law is one of the few where the tax abatement feature is granted to any redevelopment project and not limited to a housing project. This has generated some nonhousing activity under the law, particularly in St. Louis. The Conduit Industrial Redevelopment Corporation undertook a 230-acre redevelopment project in 1955. The company has exercised the power of eminent domain to acquire some of the parcels; but the condemnation has been contested and the suits are now pending in the Circuit Court of St. Louis. Another area in St. Louis has also been declared a redevelopment area under this law. Involving some seventy-seven acres, it will be used for a baseball and football stadium, parking, motel, and other commercial uses.

However, it is not only nonhousing projects that have been instigated under the

Mo. Ans. Stat. 353.120 (1952). This law applies to St: Louis and Kansas City only.

N.Y. Pus. Houstive Law 5320. 
Missouri law. In fact, Missouri is an exception to the statement that these laws have not produced the activity anticipated by their sponsors. Lewis Kitchen, who scems to monopolize this redevelopment process, has completed construction of Quality Hill Towers, a housing project adjacent to his original Quality Hill, which was built in 1950 . In addition, he has been successful in having St. Louis select him as the redeveloper under this law of a large area overlooking Jefferson Memorial Park to be used for rental housing with some commercial activities.

One feature of the Missouri law that may be partially responsible for the activity it has generated is its more generous limitation on return. Most limited dividend laws restrict the return to six per cent of the value of the stock or investment. The Missouri law, however, establishes a limit of eight per cent on the total cost of the project, including land. These net earnings are determined by deducting from gross income the costs of maintenance and operation, taxes, assessments, insurance premiums, and "an annual amount sufficient to amortize the cost of the entire project at the end of the period." This period is not to exceed sixty years.

St. Louis and Kansas City have a different policy in applying this tax abatement feature for those projects that come under Title I of the federal law and which, therefore, are entitled to write-down. St. Louis has the policy of granting both write-down and tax abatement. Kansas City takes the position that these are alternate methods and the redeveloper may choose which method he prefers. Kansas City will in some cases, however, allow a redeveloper to take advantage of tax abatement when he has acquired the property via the write-down method if he can show that tax abatement is necessary in order to carry out the project. This would be the case when it is necessary to achieve low rents. Kansas City has made one exception to its general rule.

The Kansas City projects have been or will be financed under FHA, which takes the position that the savings in taxes must be used to reduce rents or pay off the mortgage more rapidly. In one instance, the developer has applied fifty per cent of the savings to reduce rents and fifty per cent for advanced amortization of the mortgage.

Wisconsin is one other state where there has been some activity under the limited dividend law. In 1948 a proposal was made to redevelop a city area under its provisions; but it failed to receive the sanction of the city. More recently, in 1959, a proposal was advanced to undertake a development in the downtown area. In this - instance, however, the city council approved the project, and it is now underway. The Wisconsin law, like the Missouri law, does not limit the use of the limited dividend operation to housing projects. Commercial and industrial projects may also be undertaken.

The theory behind the tax abatement feature and the granting of eminent domain authority to limited dividend corporations is fairly clear. With no funds available to write down the cost of the land to a point where it would be financially feasible

- Wis, Stat. \$S 66.405-425 (1957). 
for private builders to undertake redevelopment projects, some financial means had to be employed, a means that did not require the appropriation of money by the municipality. The tax abatement feature in this sense does not cost the municipality any money since its income from the property is at least as great after redevelopment as before redevelopment. If the area were not redeveloped, the income from taxes would not be increased. If a guarantee of no increase in taxes for a stated period of years gets the area redeveloped, the city will be ahead in the long run. A slum area will be redeveloped, and eventually the area will pay taxes to the city in a much greater amount than was paid by the area previously.

Where the city has no money to cover the write-down and where there is no. federal grant to pay for two-thirds of it, this reasoning is logical. There is a question, however, as to whether the city is really shortchanging itself if it uses the tax abatement method rather than using write-down. It has been claimed that the cost to the City of New York in granting abatement to Metropolitan Life for Stuyvesant Town will exceed the cost of the land, and that New York would have been better off had it bought the land and given it to Metropolitan. This analysis is also borne out by another project where the savings in taxes to the developer will amount to $\$ 350,000$ and the cost of the land to the developer was but $\$ 155,000$. It is also apparent that the tax abatement feature, unless it runs for many, many years, cannot attract developers to costly blighted areas. The land cost cannot be excessive, for it would then require a considerable cash outlay by the developer and his mortgage would be considerably less than the cost of the improvements plus the cost of the land. This result obviously concerns the speculative builder to a much greater extent than it does an insurance company.

When money is available from the federal government to cover two-thirds of the write-down cost, it would seem wiser for a city to follow the write-down method, rather than the tax abatement method, in undertaking redevelopment projects. The cost of the project under the former is clearly indicated. The subsidy the city must advance in order to make the project economically feasible is known by all. Cost and benefit can be clearly related.

In the case of the tax abatement method, however, the subsidy being granted is really hidden, even though it can be estimated fairly well. But it is not looked upon as a cost; it is often regarded as of no cost to the city. Thus, the relation of cost and benefit is not apparent. If the tax gimmick is, in effect, to be used to finance the city's share of undertaking a redevelopment project, there are much more suitable devices for achieving the same result.

There is, however, one area where the tax abatement feature seems acceptable. Where it is a matter of public policy to obtain as low rents as possible in a private housing development and not at the same time sacrifice quality or aesthetics, then the tax abatement feature, when coupled with the write-down, can provide a subsidy to the tenants of such a project. In the event such a subsidy is granted, it would scem only sensible to require some degree of control over the rents to be charged. The 
limitation of earnings, a provision already in the law, is perhaps the simplest and most direct means of exercising this control.

Nonetheless, even in the case where the city wishes to subsidize rents, it would still seem a wiser public policy to administer such a subsidy in direct and open fashion, perhaps limiting the subsidy to those most in need, and not making it a hidden subsidy, unnoticed and, therefore, frequently ignored as a factor in determining public policy.

\section{B. Special Tax Levies}

Several states have passed legislation permitting municipalities to levy a special tax for redevelopment purposes. The reason for such legislation is frequently to permit the city to exceed the tax rate ceiling established elsewhere. In all cases these levies must be approved by the governing body of the city, and the amount of the levy is based upon a budget submitted by the redevelopment agency. It is nothing more than an appropriation except that it has somewhat greater visibility because it is labeled a special levy for urban redevelopment.

The Minnesota law ${ }^{5}$ permits redevelopment authorities to levy a special redevelopment tax not to exceed ten cents on each \$100 of taxable valuation. In Minneapolis this tax has been levied continuously since the redevelopment program was organized in 1947. The funds have been used to pay the local costs of financing redevelopment projects. The redevelopment authority has also used these funds to finance planning expenditures.

Michigan permits a similar tax levy, ${ }^{6}$ and Hamtramck is applying a one mill levy for redevelopment. Nebraska also permits such a special tax. ${ }^{7}$ Indiana ${ }^{8}{ }^{8}$ provision is almost exactly like Minnesota's. Indianapolis has been levying such a tax since I946, levying the full rate of one mill for the first two years. The city's total income from this tax through 1959 was nearly three and a half million dollars. Indianapolis has never availed itself of federal funds because of Indiana's strong feelings against accepting federal aid.

These levies do have the advantage of giving redevelopment a somewhat higher status in seeking a share of tax revenue; and they also have the advantage of being cumulative, thus permitting the redevelopment agency to accumulate funds for future projects. So long as the redevelopment agency is required to submit budgets to support the amount of the levy requested, no violence is done to the basic-fiscal principle that the governing body must make the final decision on the distribution of available revenue among competing municipal demands. Certainly, these laws have made it possible for some cities to go ahead with redevelopment where obtaining appropriations of like amounts might have been much more difficult.

- Mins. Stat. Ans. 5462.545 (Supp. 1959).

- Mich. Stat. $\$ 5.3507(3), 5.3526(3)$ (1957).

'Neb. Rev. Stat. 19-2640 (Supp. 1957).

- Ind. Ann. Stat. 5 48-8562d (Supp. 1960). 


\section{Redevelopment Revenue Bonds}

California has a constitutional amendment and has passed enabling legislation permitting cities to issue tax allocation bonds secured by only the increased tax revenues from a redevelopment project. ${ }^{9}$ Receipts from the sale of these bonds are used by the city to meet its one-third share of the cost of the project. Specifically the law provides that the taxes collected from property in a redevelopment area on which tax allocation bonds have been issued be distributed as follows: The taxes derived by applying the tax rate to the assessed valuation of the property prior to its redevelopment is distributed to the various local taxing bodies in the usual manner. The balance of the tax receipts is segregated in a special fund which is used to retire, and pay interest on, the tax allocation bonds.

Sacramento is the first California city to utilize this provision, and Sacramento's pioneering was successful. In August 1956 it sold a two million dollar bond issue on its Capitol Mall project at a rate of 4.4983 , a rate from one to one and a half per cent higher than the rate for Sacramento's general obligation bonds, but considerably less than most improvement district bonds. This bond issue was of particular importance to Sacramento because of the failure of the voters to approve previous general obligation bond issues. California requires that such bonds receive a twothirds vote. Sacramento's vote was not up to two-thirds, but it was over one-half. No referendum is required for these revenue bonds. Minnesota ${ }^{10}$ has a similar provision, but it has not been used. Nor has any other California city yet made use of this provision, although Los Angeles at least intends doing so.

The segregation of tax revenues for specific purposes-highways, parks, schools, redevelopment, and the like-is generally frowned upon by students of public finance. Such action removes from the governing body the freedom to weigh the demands for funds. Segregated tax revenues assure expenditures for certain items when the city council may feel that the need is greater elsewhere; this policy removes a particular function from measurement against the needs of other functions.

In this instance, however, the argument does not apply. The decision of the governing body is whether to appropriate money from current funds to undertake the project, or whether to issue bonds to pay for its share of the cost. The fact that the bonds are to be supported by increased revenues from the project does not alter the basic decision. General obligation bonds could be retired the same way; and so this is not an instance where the segregation of tax revenues for special purposes applies.

This does not mean, however, that it is always advisable to issue tax allocation bonds to finance redevelopment projects. It is a useful procedure where other methods cannot be used and does no violence to the principle of nonsegregation of

- Cal. Const. amend. XIII, $\$$ 19; Cal. Health \& Safety Code 33950 . Nevada has incorporated the entire California Community Redevelopment Law in its statutes and so includes the tax allocation bond provision. NEv. Rev. SthT. \& 279, 676 (1957).

${ }^{10}$ Minn. Stat. ANN. 5462.545 (Supp. 3959). 
tax revenues. But it is not so advantageous a method as issuing general obligation bonds.

General obligation bonds can be sold at a lesser interest rate than revenue or tax allocation bonds, and this interest can be a sizable item. The same argument can be used in selling general obligation bonds to the voters as is used in selling the tax allocation bonds to the purchasers. It makes no difference whether the increased taxes are placed in a separate fund or whether they are commingled with other general revenues. In either case, it can be demonstrated that the amount of the increased taxes will pay off the bonds in a stated number of years-feiver years for general obligation bonds; more years for tax allocation bonds, since the interest rate is greater.

Revenue bonds or tax allocation bonds for financing the locality's share of net project cost should be employed only when it is impossible to use general obligation bonds, assuming that bonds will be used in any case to finance the city's share. The only two instances where it would seem advisable to use these bonds rather than general obligation bonds are: ( $I$ ) when the city has reached its bonded indebtedness limit; or (2) when bond issue referenda are unsuccessful. Revenue bonds are generally exempt from both of these limitations and thus can be employed when these limitations stand in the way.

\section{Tax Concessions for Property Improvement}

Recently there has been an increasing emphasis on the proposal that the property tax be used as a device to encourage the property owner to rehabilitate his property and thus accelerate the urban renewal program, where rehabilitation is one of the objectives. The proposal usually takes the form of freezing the existing assessment if the property is improved-i.e., the new improvements will not be assessed.

The argument supporting this proposition is based on the idea that the propertyowner is being penalized when in fact he should be rewarded. When a propertyowner improves his property, its value is increased; and consequently so is the assessment. The increased assessment increases the property tax; and, so goes the argument, the property-owner is discouraged from spending money on improvements. Conversely, the argument runs, if the property-owner does not have his assessment increased, he will be encouraged to fix up his property.

This proposal is a misuse of the taxing power and is also discriminatory. It grants no tax relief to the property-owner who maintains his property and benefits the property-owner who has allowed his property to deteriorate. It also violates the basic principle of the property tax; namely, that the incidence of the tax should be based upon the value of the property owned. It is also a hidden subsidy in that it seemingly encourages action without cost to the city. In fact, it is both a cost to the city and a cost, in terms of increased load, to the property-owners who have consistently maintained their property.

Also, it is not at all certain that an increase in assessment because of property 
improvement is a deterrent to improvement. There is always a vocal group of property-owners who proclaim the inequity of an increased assessment, but this vocal group is not necessarily a majority. No one, of course, wishes to pay higher taxes; those who must pay often have a tendency to see injustices in an increase. But, the possibility of an increased assessment because of improvements to one's property is not necessarily a deterrent from making improvements.

For the property-owner who rents his property, the failure to increase the assessment is clearly a windfall. He will, of necessity, increase his rents to cover the value of his improvements; and if income is any measure of value, he should logically pay taxes commensurate with owners of property of similar value.

If it is the policy of the city to subsidize owners to improve their property, it would seem a much wiser course for the city to grant a direct subsidy to such owners to encourage them to do so. Actually, under FHA's financing provisions relating to urban renewal areas, the intent of the legislation is to encourage property-owners to undertake improvements by granting them more favorable financing terms than they could obtain elsewhere. The fact that the administration of these FHA provisions has not produced the desired results does not detract from the use of this method as the carrot rather than the freezing of assessments.

\section{E. Summary}

In all these instances except the special tax levy-tax abatement, segregation of increased tax revenues, freezing of assessments to property-owners-the purpose is the same-namely, the creation of a device that will make the cost of undertaking urban renewal painless or at least less painful than the usual means of meeting municipal costs. The special tax levy is a straightforward means of meeting the cost of the program so long as it is reviewed by the governing body and its demands weighed against other municipal needs.

Of the other devices, the segregation of tax revenues for tax allocation bonds is also a straightforward method of raising revenue for the program. It does not run afoul of the principle that tax revenues should not be scgregated-even though on the surface it appears to do so. It is merely an alternative to annual appropriations to meet the cost, or a substitute for general obligation bonds where they are not possible because of debt limitation or special referenda requirements. State legislation authorizing cities to use such a device should be adopted by many more states. This is an area where the states can be of considerable help.

Tax abatement to the redeveloper is another matter. Its purpose is the same as the use of tax allocation bonds; the increased revenue from the project is used to pay the public costs in carrying out the project. Where tax allocation bonds are used, the cost is clearly stated and the method of payment is in the open. In the case of tax abatement to the redeveloper, the increased tax revenue from the project is, in effect, returned to the developer as a substitute for the write-down. There is no measure between write-down and tax savings, as there is where tax allocation bonds 
are used; and yet it is the same source of income that is being employed to meet municipal costs.

A basic principle where subsidy is being employed is that its amount should be clearly determinable and that the recipient should be clearly identifiable. In tax abatement, the amount of the subsidy is not clearly determinable, even though one can compute the tax for the number of abatement years. The effect of an annual reduction in operating expenses has a much different effect than does the reduction in the price of the land.

In tax abatement the recipient of the subsidy also is not clearly identifiable; it appears to be the redeveloper, but is not. Where write-down is used, the subsidy is not to the redeveloper; it is to the city for its past errors and for its faith in the future. The redeveloper pays the fair reuse value of the land. The tax abatement principle is but a substitute for the write-down; the subsidy again is not to the redeveloper, but to the city. However, because the amount of the subsidy is not easily determinable, one is not sure whether the redeveloper is in fact receiving a subsidy he would not receive were he to acquire the land through the write-down method.

And finally, where it is a question of choice as between write-down and tax abatement, clearly it is to the city's advantage to use write-down, for the cost to the city if it goes the federal route will be but one-third of the project cost. In this same vein, it is also clear that a redeveloper will not employ the tax abatement method unless the benefit is as great as would be the benefit if the land were to be purchased at its fair reuse value.

The only cases where it would seem desirable to employ the tax abatement method are: (r) where because of no enabling legislation opportunity is lacking to use the write-down approach; and (2) where it is to be used as an additional incentive to produce lower rents in the first several years of the project. Tax abatement is a tool that must be used carefully if the city is not to be hurt.

Assessment concessions to homeowners to encourage property improvement require no additional comment. They are a misuse of the taxing power and are discriminatory. They should not be used.

In this particular area, therefore, the idea of the special levy is an acceptable and often a helpful means of financing urban renewal. The use of tax allocation bonds is also a useful device where other means of financing fail; it is an additional tool that the states should give their municipalities.

II

\section{State Assistance}

Several states have recognized the great demands upon localities for funds to undertake urban renewal projects and as a consequence have appropriated funds to assist their cities in meeting local urban renewal costs. These funds are distributed through a state board which in many cases is also organized to provide 
technical assistance. The states where funds have been appropriated for the purpose of providing financial assistance for urban renewal are Connecticut, Illinois, New York, and Pennsylvania.

\section{A. Connecticut}

In 1958, Connecticut enacted two laws authorizing grants to municipalitics for urban renewal projects. One act authorized a $\$ 10,000,000$ bond issue to finance direct grants for urban redevelopment projects."11 Grants are made for specific renewal projects that have received federal approval for financial assistance, and the amount of the grant is equal to half of the locality's one-third share. The program is administered by the Connecticut Development Commission, which has established rules and regulations for approval of projects and distribution of the funds. Nearly all of the money has been authorized for specific renewal projects.

The second piece of legislation enacted by Connecticut is concerned with industrial and commercial renewal projects ineligible for federal assistance. ${ }^{22} \mathrm{~A}$ bond issue of $\$ 5,000,000$ was authorized to finance this program, and it, too, is administered by the Connecticut Development Commission. The legislation was enacted at a time when little federal money was available for such projects. The federal legislation in 1959, however, increased the amount of grant money and eased the regulations. This has reduced the demand for state funds, for which the terms are not as favorable as under the federal legislation.

Under Connecticut's nonresidential redevelopment legislation, a project must be ineligible for federal aid before it is eligible for state aid, and this ineligibility must be demonstrated by submitting a final project report to the federal government. If the project is ineligible for federal aid, the state will pay half the cost of undertaking the project and will advance funds equal to seventy-five per cent of the planning costs. There is no provision for a temporary loan as there is under the federal law, so the municipality must raise its own funds for the purchase of the land. These provisions have generally discouraged much participation by Connecticut municipalities. New Haven and Hartord, however, each have one project underway under this law.

Connecticut has a third law which is related to urban renewal although it does not provide direct assistance to urban renewal projects. This law provides financial assistance to cities to assist them in preparing a capital improvement program. ${ }^{13}$ Under this program, which is also administered by the Connecticut Development Commission, the state agrees to pay half of the cost, up to $\$ 3,000$.

\section{B. Illinois}

In 1947, Illinois adopted legislation authorizing grants to land clearance commissions for urban redevelopment projects. ${ }^{14}$ The legislature appropriated $\$ 10,000,000$

"Cons. Gen. Stat. Rev. 5 8-152 (1958).

$321 d .58 .157$ (1958).

12 Id. 55 8-161, 162 (1958).

24 ILI. AN.S. STAT. ch. 671/2, \$\$ 55-62 (2959). 
for urban redevelopment grants and established a formula for its distribution, relating. the amount to the population of the area in which the land clearance commission had authority. There was also a provision for the distribution of the grants unused by land clearance commissions. By now the entire $\$ 10,000,000$ has been distributed.

These grants were administered by the Illinois State Housing Board, which was. required to review the application for need and to review and approve the particular project for which the money was to be used. In the early days of the federal program, field representatives of the State Housing Board felt it was their job to spread the gospel on urban redevelopment and to point out the availability of state and federal funds. As a result, there was an early rash of "reservations" of federal capital grants. by many small Illinois communities. Only a few of these communities, however, actually undertook redevelopment projects. For the most part they were not adequately prepared or staffed to carry out projects, and in many cases the community itself was not sympathetic to the program. The appropriation for state grants, therefore, went to those communities that actually undertook redevelopment projects. No further appropriations have been made under this act, and all Illinois cities. must finance their local one-third share of project cost locally.

\section{New York}

New York has authorized subsidies to municipalities to assist urban renewal. ${ }^{23}$ The Commissioner of Housing is authorized to enter into contracts with municipalities to make periodic subsidies to assist in the clearance, replanning, reconstruction, and rehabilitation of substandard and insanitary areas pursuant to any law author-izing municipalities to establish and carry out a federal program of urban renewal. with federal aid.

\section{Pennsylvania}

Pennsylvania has had the most active and the most generous urban redevelopment. assistance program. The legislation was enacted in 1949 and with it went an appropriation of $\$ 15,000,000$ to assist both housing and urban redevelopment. ${ }^{16}$ In 1955 an: additional $\$ 5,000,000$ was appropriated; in $1957, \$ 2,800,000$; and in $1959, \$ 5,000,000$. As of April 30, 1960, the state had entered into contracts with cities amounting to nearly $\$ 13,000,000$ in state grants for urban redevelopment and had spent one and a quarter million in grants to assist local housing projects. The result has been to. stimulate Pennsylvania localities to undertake redevelopment programs and to encourage many small localities to participate in the program. By April 30, 1960, some forty-nine localities had entered into contracts with the state for specific redevelop-ment projects.

Under this program the state will make grants to localities to assist them in. planning redevelopment projects and to help them meet their local one-third shareof project costs. The planning advances have been used to speed up the planning:

38 N.Y. PuB. Housing Law $\$ 73$.

10 PA. Stat. Ans, tit. 35, 51664 (Supp. 1959). 
process. Even though a locality may receive federal advances to undertake the planning of a redevelopmeni project, the state established a policy of making planning grants at the time the locality submitted its application for a planning advance, on the theory that the delay between application and approval by the federal government was so great that valuable time was lost.

On grants to help the locality meet its one-third share of project cost, the state has placed but one monetary limitation-namely, that the money spent by other state agencies and claimed as a local noncash grant in aid by the locality be deducted when computing the state's share of half the local contribution.

The program is administered by the Bureau of Community Development of the Pennsylvania Department of Commerce, and it has been administered wisely and well. For the most part, the state agency relies upon federal review of the projects rather than establishing its own set of technicians. If the federal government approves the project, the state goes along.

A third type of grant just recently established under this program is a grant for "core studies." These grants, which are for the purpose of studying and planning "core areas" or downtown areas, are made before a locality submits an application to HHFA for a specific downtown project. The state will match the amount the locality will spend on such studies, and this grant is credited as part of the state contribution to the first project undertaken within the core area.

In making grants for these core studies, the state is requiring the planning consultants to make forecasts or projections of population, financial activity, employment, traffic, and the like. Thus they are designed to require a city to undertake a thorough analysis of its downtown area. As a result, Pennsylvania cities will be in an advantageous position to make use of federal funds for downtown projects.

\section{E. Analysis of State Programs}

There is little question that localities need financial assistance to undertake redevelopment projects, and state aid in this field can provide welcome assistance as well as an important stimulus. This is particularly evident in the comprehensive and forward-looking program undertaken by Pennsylvania. It is unfortunate that more states have not adopted programs of this nature, for the effect can be farreaching in the redevelopment of urban areas, particularly in the smaller community.

The smaller community is hard pressed to generate the funds needed to undertake a redevelopment program, and "seed money" provided by the state can do much to make the program feasible. It is here also that the states can provide encouragement through the provision of technical assistance. If the state agency could maintain a staff of technicians, not large in number, to give guidance to the smaller localities who lack the resources to employ well-trained people in this field, those smaller localities could be fortified with the "know-how" to undertake urban renewal programs. 'Technical assistance and the use of state grants to encourage cities 
to undertake projects and studies that will help them understand their city and its needs could achieve a considerable increase in urban renewal activity. The adoption of such programs, however, will first require a recognition on the part of state legislatures of the importance of their urban areas.

With any kind of financial assistance, however, goes some degree of control; and it is only natural to expect the state to exercise a review function if it is to grant financial assistance. There is always the iendency to second-guess the decision of the locality when the state's money is being used to help finance the project. Pennsylvania's practice in this respect has been exemplary. With a detailed federal review of projects, the state has rightly concluded that an additional detailed review is unnecessary and has relied upon the competence of the federal officials. As a result, the program has provided the stimulus and the needed financial assistance without imposing another level of governmental review. The danger, of course, is that state agencies will not exhibit the admirable restraint shown by Pennsylvania.

With a program as complex as urban renewal, the imposition of an additional level of detailed governmental review would encumber it to the point where achievement would be most difficult. Local review by the city council, citizens' committees, the planning commission, and others is already heavy. 'This is topped by a detailed federal review and a measurement against detailed federal requirements. A third, state-level review in any detail would make the program unwieldy.

In discussing the role of the states in providing financial assistance for urban renewal, some mention should be made of the proposal advanced that the states assume all or a portion of the federal grants for urban renewal. If this were to come about, the program would be reduced tremendously. The states have their own financial problems and are in no shape to provide the kind of grant money necessary to keep the program rolling. Present state grants are made on the basis that their cities are financially unable to meet the entire local cost of the program, and thus they are willing to supplement federal aid to move the program along. This is where state aid is needed; it cannot become a substitute for federal aid.

\section{III}

\section{Local Governmentaz Assistance}

Unfortunately, many local officials look upon urban renewal as essentially a real estate program-a program where clearance is the objective and where the operation . is limited to acquiring property, relocating families, demolishing structures, installing public improvements, and selling the cleared land to a developer. There is some limited recognition of the importance of cooperation from the various municipal departments that are involved in the operation, but the really important role of these peripherally involved departments is not emphasized. As a result the area where local government can provide the greatest assistance is an area where local government falls far short of its potential.

It has become a truism to say that urban renewal is a complicated program. It 
is! But this is all the more reason for concentrating on its complexities and solving the complex problems. Too often, instead, the statement is accepted as an excuse for ignoring the problems and producing inadequate solutions.

For the first time, local governments are dealing with areas-not with a particular, easily defined project. They are improving an entire are - nct inst building a strect, developing a park, or changing street lights. Cities should be concentrating and coordinating their efforts in these areas; in truth they are not. Urban renewal is but another department or agency. The departments function as always. There is no hard, driving direction to achieve a coordinated city program in an urban renewal area.

For urban renewal is far more than acquisition, relocation, clenrance, and disposition. It is the creation of a new area in a new image, or the remolding of an old area in a new image. Creation and remolding do not result from clearance and rebuilding alone. They result from concomitant municipal activities whose absence or misapplication can destroy the image.

And redevelopment and rehabilitation cannot be carried out by private developers acting within a governmental framework similar to that found in the development of new subdivisions. The city itself must be a partner to the development, assisting the operation wherever possible, for urban renewal uncovers problems untaced by the subdivision developer, and these problems are costly in time and money if public help is not granted.

There are three basic areas where the city has lagged far behind its obligations in providing assistance to urban renewal. These may be classified generally under the heading of aesthetics, zoning, and administration.

\section{A. Aesthetics}

One must start with the premise that the city's objective is the creation of new urban areas with decided improvement over standard urban living patterns. If this were not the premise, if we were content with perpetuating that which we now have, the lift would ieave the program, the drive to achieve beauty and livability would be gone. And we would be misusing our effort and money.

So one starts with the premise that we are aiming high and that our standards should be high. And we find, fortunately, that architecture is playing an important role and that America's best architects are involved in urban renewal. They strive to create beauty and they strive to create urban livability. And in many instances, they have been successful.

However, on the public side, one finds too often an unawareness of this objective. One finds a disinclination to produce public structures of any distinction because of the controversy such a structure might create, or because aesthetics plays no role in the design or the objective. New schools in redevelopment areas rise adjacent to well designed buildings; yet little thought is given to creating architecture of comparable quality. The redevelopment agency frequently selects a redeveloper on the basis of 
the design submitted by his architect, but the city may select the architect for the new school on grounds unrelated to design ability.

This criticism is not limited to new schools. It applies to nearly all public structures in renewal areas. This drive for design excellence stays with the redevelopment agency and is not transmitted to other city departments. The great interest in creating a desirable new area is not shared by the rest of the city government.

So the great design effort becomes diluted. The well-designed private structures share the area with the indifferently designed public structures. It is strange that this is so since it has been the private builder who has been criticized severely for his unimaginative buildings. But now the private builder leads the public.

Aesthetics does not apply just to structures. It applies also to such items as street lighting, where the traffic department wants to install modern, high, very bright street lights in an an area that is supposed to be a quiet, residential community. But lighting standards are measured not by aesthetics but by standard "advanced" design. The character of the area is not considered.

Then there is the recreation area and the standards applied to determine its design. In an area where one expects many adults, the need is for adult recreation. But the design is standard for the children's playground-large areas of asphalt, no tennis courts, and a high metal fence surrounding the whole. The fence cannot be covered with ivy for it must be painted every given number of years. A hedge serves not as well (one can crawl through it), so it is discarded. The recreation space is designed with little relation to the kind of area it is to serve. No direction, no vision, has been given to assist in the creation of a new kind of urban area.

And then there are the streets-streets that are minor and slow-moving must be widened to meet standards for much greater movement, and with their widening come down the trees. Little thought is given to the preservation of the trees that can provide much of the area's chaim and attraction. The standard must be applied. There is no over-all controlling design that directs the other city departments in the installation and design of their facilities.

Somehow this direction and over-all design must be imparted to the other city departments. They must realize that an area is ueing rebuilt-not just a new school being buil, or a recreation area designed, or a street being resurfaced. They must somchow be made to see that the design of what they build is a part of the design of the area being created. The city must create the design objective and must insist that these objectives be observed by all city departments, as well as by the private developer. Only a few cities now pay adequate attention to comprehensive design.

\section{B. Zoning}

The antiquity of the average city's planning laws and procedures creates an obstacle to urban renewal that frequently prohibits the attainment of the urban renewal objective. Zoning is the major villain. Designed to meet the planning objectives of the thirties and written for the single lot and its protection from adjacent 
users, it is unsuited for the planned renewal area. Zoning is a major stumbling block to achieving the objectives of large-scale urban renewal.

Eli Goldston and James $\mathrm{H}$. Scheuer have gone into this subject in penetrating detail in their recent article "Zoning of Planned Residential Developments." emphasize the difficulty of achieving the kind of urban design proposed by major urban designers for urban redevelopmeni projects under the rigid, zoning ordinances in most cities. The cumbersome side-yard requirements, setbacks, building envelope, space between buildings, and so forth, dictate the design of these areas, rather than the designer.

Good design in these redevelopment areas has been achieved in spite of the zoning ordinances by various means, usually by appeal to the board of zoning appeals or its counterpart. In some instances, the zoning ordinances have been amended to permit the design proposed. In Washington, $\mathrm{D}$. $\mathrm{C}$., the redevelopment plan takes precedence over the zoning ordinance. ${ }^{18}$

The difficulty of living within the framework of the zoning ordinance is apparent. Since it is designed for the single lot and since it reflects a philosophy of segregation of uses and housing types, it clearly restricts a development which is large-scalethat is, designed as an area, rather than as a series of buildings on individual lots, and which is based upon a philosophy that seeks to mix uses and housing types as part of the design. The acceptance of this philosophy is general among planners today, and yet the zoning ordinance, which is the planner's major tool in urban development, precludes the achievement of this philosophy.

Goldston and Scheuer suggest as a remedy the planned development district, a device, as they point out, emplayed by only half of the larger cities in the United States. Their analysis of those ordinances which include a planned development district indicates in many instances that they are cumbersome; and these writers have proposed a model provision that could be adopted as an amendinent to most zoning ordinances. Their model limits such districts to residential districts, and they rely upon a board of zoning appeals to make the final decisior as to the acceptability of the proposed planned development.

If planned renewal areas are to be developed in patterns of new urban design, evidently a device is essential to override the rigidity of the zoning ordinance. The planncd development area provision is such a device. Of necessity, it must rely upon the judgment of local officials if flexibility is to be achieved; for, if specifics art: to be cxcluded, judgment must be substituted. This creates a vehicle that will permit new urban design and planned renewal areas, but it does not guarantee that the judgment of the final arbiter will be sympathetic to the concept of the planned

\footnotetext{
${ }^{17}$ Goldston \& Scheuer, Zoning of Planncd Residential Developments, 73 HARv. L. Rrv. 242 (1959).

14 See opinion of District of Columbia Corporation Counsel, Vernon E. West, submittcl to the Board of Commissioners Fcb. 2, 1956. His opinion is summed up in this sentence: "Accordingly I can only conclude that in a given project area the selevelopment plan prevails over any existing or propoved Zoning Regulations."
} 
district. This can be achieved only if the city insists that those who make the judgments reflect this kind of planning philosophy.

Specifically, the planned development provision of the zoning ordinance should not be limited to residential development, since many renewal areas are nonresidential and require area-wide design as much as do residential areas. It would also seem best to place the final design decision in the hands of the planning commission, rather than the board of zoning appeals. The latter body is usually more limited in its appraisal of planning concepts and deals with small-scale, individual problems rather than large-scale developments. Also, it does not have a planning staff comparable to that of the planning commission. Adoption by the city council may be a necessary legal step, but the procedure should not be encumbered by introducing the zoning board.

Such a zoning provision should also give the final arbiter considerable latitude in establishing over-all densities, land use, coverage, and the like, rather than try to spell out certain limits or standards in the ordinance itself. The mathematical standards upon which zoning ordinances rely so heavily are themselves judgments applied to individual lots on a city-wide basis. They have no real validity for judging the design of a large area.

The renewal plan itself usually cannot serve in the capacity of the design for a planned area, for the renewal plan should be a general plan permitting the designer considerable flexibility. Or, if it is a detailed, rigid plan, then it will contain within itself the kind of zoning regulations that inhibit good design. The planned area provision must provide for the review of a specific design which will show location of buildings, heights, uses, and so forth. It is in the review of this specific design that the city assures itself that its basic objectives are met. The burden of proof is upon the designer. The city, however, should apply the standards of function and achievement, rather than the mathematical standards of the zoning ordinance, in reviewing the proposal.

Without this kind of flexible planning device, the cities will continue to impede new ideas in urban design. By means of this flexible planning device, the cities can provide a procedure that permits achievement of new heights in urban design. It is through such a device that the city can make a substantial contribution to the urban renewal program.

\section{Administration}

The zoning question has been treated separately since it is of such importance, but it is also a part of urban renewal's local administrative apparatus. And this apparatus is something to behold. It is an apparatus unsuited to the renewal operation and one that costs the city dollars and time. Its remolding into an efficient and effective procedure is one other way in which the city can contribute to the urban renewal program.

But before an effective apparatus can be adopted, the city's administrative organization must understand the urban renewal process and be sympathetic to its ob- 
jectives. Too often the administrative heads give only lip service to urban renewal, for frequently it means that the procedures to which they have become accustomed must be altered and that their compartmentalized objectives must often be modified to meet the larger objective of the renewal plan. By reason of the present attitudes in the hierarchy of most cities, the department head can frequently exercise a veto power when he disagrees with the plan as it relates to his particular department.

Then, too, the philosophical objective of the renewal plan is frequently opposed by some of the city's civil servants, and a discrediting of the whole operation takes place in a quiet way within the city hall. This independence and lack of rapport makes the task of creating a renewal plan and getting it developed very difficult, frustrating, and time-consuming.

However, that this should be the case is not strange, for urban renewal presents an entirely new process to the city and its administrative heads. It requires action by nearly all city departments in one way or the other, rather than the exccution of a project that is controlled by just one department. There is, of course, some coordination among departments for some city activities; but under urban renewal, where an entire area is being renewed, each department plays a role. Traffic, streets, fire, police, schools, parks, sewers, water-all these must be fitted together to create a renewal plan. Each department has rather fixed ideas of what it wants to do and the standards that should be applied; more often than not, the timing and standards conflict. This is particularly true in regard to standards where the urban design is new and different.

So the city must address itself to the administrative machinery of urban renewal and establish strong leadership to achieve the objectives of the urban renewal plan. It cannot permit each administrative head to exercise veto power, and it must establish a machinery that puts the renewal plan objective above the objective of any particular department.

This has not gone unnoticed in several cities, although generally most cities have not yet organized themselves for an effective renewal program. New Haven, with a development coordinator who is in charge of the renewal program as well as other development aspects of the city's activities, has produced an effective urban renewal organization. The power and drive of the mayor has, of course, made such a strong renewal operation possible.

Philadelphia has also established the machinery for an effective organization, although it has not been able to function with the same efficiency as has New Haven. Baltimore has initiated the single-department idea - or rather almost the singledepartment idea-and has put it into effect with a new and almost all-inclusive agency. Obviously such an agency cannot perform all the functions required of many city departments. Yet such an agency does exercise the urban renewal operating functions such as code enforcement, clearance, and relocation, and also has sufficient importance to obtain the coordination and cooperation necessary from other city departments. 
Baltimore, in fact, undertook a special study of this organizational question and called upon the best experts in the field to produce a solution. This study is worth review by any municipality interested in improving its organization for urban renewal. In addition to providing a proposal for an urban renewal organization, the study analyzes cogently the administrative problems confronting urban renewal. Many passages are worth quoting, but the following is particularly appropriate: ${ }^{19}$

The internal problems facing each of the agencies engaged in urban renewal have been further complicated by the extraordinary need for coordination between them. At least 2 dozen different agencies, departments, and bureaus in Baltimore's municipal government now have some interest in urban renewal. Any enforcement effort can generate sustained community improvement only if it is coupled with improvements in municipal services, the installation of needed community improvements, the elimination of hopelessly substandard units, and the active participation of the residents of the area affected. This means that all departments of municipal government must participate actively, aggressively, and with sympathy and understanding in a total program aimed at the rejuvenation of $a$ neighborhood.

It is in this field of administration that the city can contribute greatly to the progress of urban renewal. Administrative rejuvenation requires the direction of a strong leader, an executive who has the authority to prevent established department heads from vetoing the process that will make urban renewal work.

IV

\section{SUMMARY}

Unquestionably one of the major assists to urban renewal by the states is in the provision of state grants to help cities meet the local costs of the program. Such assistance provides a considerable stimulus to the program and gives recognition to the state's responsibility to assist financially in the rejuvenation of its urban areas. Too few states have recognized this responsibility.

The states can also provide some assistance and stimulus by adopting legislation permitting cities to utilize various devices to assist them in their urban renewal programs. Although the use of tax allocation bonds is helpful, it is basically a device to circumvent existing state limitations on borrowing power and procedures. State legislation granting municipalities greater authority in borrowing and establishing less rigid referenda requirements could achieve the same result. Tax abatement provisions, on the whole, are an anachronism-a holdover from the thirtiesand should be re-examined if they are to be used. Their value is doubtful.

It is to themselves, however, that the cities should look for improvement in the urban renewal program. Most cities, not recognizing the basic difference in the development aspects of the two programs, use the same approach for urban renewal programs as is used for public housing projects. Cities are also using an admin-

io Report of the Baltiatore Urban Renewal Study Board to Mayor Thomas D'Aleshndro, Jk, $S$ (1956). 
istrative machinery geared to the installation of public improvements rather than the remaking of large areas, and this machinery is demonstrably both inadequate and detrimental to the achievement of urban renewal objectives. Although cities can legitimately and with justification look to the federal government for financial assistance, they have been somewhat less than effective in looking to themselves for self-improvement in the administration of the program. 